\title{
Studi meta analisis: Efektivitas progressive muscle relaxation untuk menurunkan kecemasan orang dengan penderita penyakit kronis.
}

\author{
Nur Fadillah"*, Ananta Yudiarso ${ }^{2}$ \\ ${ }^{1,2}$ Fakultas Psikologi, Universitas Surabaya, Indonesia
}

\begin{tabular}{l}
\hline Info \\
Artikel \\
\hline Sejarah Artikel: \\
Diterima \\
OI September \\
2020 \\
Direview \\
OI September \\
2020 \\
Disetujui \\
04 November \\
2020 \\
Dipublikasikan \\
I5 Januari 202I \\
\hline Keywords: \\
Progressive, \\
muscle relaxation, \\
anxiety, \\
meta-analysis
\end{tabular}

meta-analysis

\section{Abstrak}

Objektif: Kecemasan sering terjadi oleh siapapun, terutama yang memiliki riwayat penyakit akan memiliki tingkat kecemasan yang lebih tinggi. Progressive muscle relaxation merupakan salah satu pengobatan non farmakologis yang dapat digunakan untuk menurunkan kecemasan. Tujuan dari penelitian ini untuk mengetahui efektivitas progressive muscle relaxation dalam menurunkan kecemasan.

Metode: Menggunakan meta-analysis berupa review literatur 14 iurnal penelitian internasional. Total partisipan sebanyak 1.022 yang terdiri dari kelompok kontrol sebesar 516 dan kelompok eksperimen sebesar 506. Analisis data menggunakan website Meta-mar. Peneliti menggunakan pedoman dari PRISMA dan MARS.

Temuan: Dengan menggunakan analisis statistik cohen's $d$ effect size, diperoleh hasil pengolahan data yaitu mean (M), standar deviasi (SD), dan sample size (N) menghasilkan effect size dengan menggunakan random effect dengan Hedges'g sebesar $0.8 \mathrm{I}, 95 \% \mathrm{Cl}=0,224$ sampai I.40I dengan nilai Inconsistency $\left(\mathrm{I}^{2}\right)=94,5 \%$. yang berarti bahwa progressive muscle relaxation memiliki efek yang besar untuk menurunkan kecemasan.

Kesimpulan: Progressive muscle relaxation memberikan efek yang besar dalam menurunkan kecemasan.

\section{Meta-analysis study: Effectiveness of progressive muscle relaxation to detract anxiety in individual with chronic illness. \\ Objectives: Anxiety often occurs by anyone, especially those who have a history of the disease will have higher levels of anxiety. Progressive muscle relaxation is a non- pharmacological treatment that can be used to reduce anxiety. The purpose of this study was to determine the effectiveness of progressive muscle relaxation in reducing anxiety.}

Method: Using a meta-analysis in the form of a literature review of 14 international research journals. Total participants are 1,022 comprising 516 for the control group and the experimental group of 506. Data analysis using the Meta-mar website. Researchers used guidelines from PRISMA and MARS.

Findings: Using cohen's d effect size statistical analysis, the data processing depicted mean $(M)$, standard deviation (SD), and sample size $(N)$ produce an effect size using a random effect with a Hedges'g of $0.8 \mathrm{I}, 95 \% \mathrm{Cl}=0.224$ to $\mathrm{I} .40 \mathrm{I}$ with an inconsistency value $(12)=94$ , $5 \%$. Which meand that progressive muscle relaxation has a great effect on reducing anxiety

Conclusions: Progressive muscle relaxation has a large effect in reducing anxiety.

\footnotetext{
*Alamat korespondensi:

Universitas Surabaya

nfadilllah.azis@gmail.com
} 


\section{Pendahuluan}

Kecemasan, stress, dan depresi merupakan salah satu faktor yang dapat merugikan bagi individu itu sendiri dan masyarakat, dikarenakan hal tersebut dapat mengarah pada hasil negatif seperti terjadinya putus sekolah, peningkatan kecenderungan bunuh diri, masalah perkawinan, gangguan kemampuan untuk bekerja secara efektif, kelelahan dan juga masalah pada kesehatan diri sendiri, maka dari itu salah satu kebutuhan yang memiliki perhatian lebih besar yaitu pada kesejahteraan psikologis.

Kecemasan berasal dari bahasa latin yaitu anxius yang berarti penyempitan atau pencekikan. Kecemasan adalah suatu manifestasi dari berbagai proses emosi yang bercampur baur, dan terjadi ketika individu mengalami tekanan perasaan dan pertentangan batin atau konflik yang terjadi (Ricky, Rachmawaty, \& syam 2018). Sarwono (20I2) menjelaskan bahwa cemas merupakan bentuk ketidakberanian ditambah dengan keresahan terhadap hal-hal yang tidak jelas. Annisa dan Ifdil, (20l6) mengemukakan bahwa kecemasan merupakan kondisi emosi yang ditandai dengan timbulnya rasa tidak nyaman yang dirasakan individu, dan merupakan pengalaman yang samar disertai timbulnya perasaan tidak berdaya. Adapun faktor-faktor penyebab kecemasan adalah lingkungan misalnya perasaan cemas yang timbul karena adanya bahaya yang mengancam individu, kecemasan yang timbul karena rasa bersalah, dan kecemasan yang disebabkan oleh penyakit yang disertai dengan rasa takut yang dapat mempengaruhi kondisi keseluruhan pada penderitanya (Rochman, 2010).

Kecemasan setiap individu berbeda terlebih lagi kepada individu yang memiliki penyakit, seperti pasien yang memiliki riwayat penyakit diabetes, kanker dan jantung bawaan, bahkan individu yang lagi menempuh perkuliahan. Kecemasan dapat terjadi pada siapapun baik yang individu normal atau tanpa memiliki riwayat penyakit ataupun juga individu yang memiliki riwayat penyakit. Kehoe (20I4) kecemasan bukan hanya terjadi pada penyedia layanan, kecemasan juga terjadi pada pasien yang memiliki riwayat penyakit dengan pengobatan seumur hidup, dengan prevalensi $31 \%$ mengalami kecemasan, seperti pada pasien penderita diabetes, (Gangdharan \& Madan, 20I8) jantung (Sulastini, dkk 2019) hipertensi (li et al., 2015), cancer, kanker payudara (Lee, Bhattacharya, Shon \& Verres, 20 I 2: Ricky, dkk 20I8), bahkan untuk pasien covid-I 9 (Liu, et al., 2020)

Riset-riset mengenai intervensi keperawatan terhadap stress dan kecemasan sudah dilakukan sejak 1890-1990. Snyder dan Egan menemukan relaksasi merupakan salah satu faktor yang dapat menghilangkan stres. Smeltzer (20l3) menjelaskan bahwa teknik relaksasi merupakan metode utama yang dapat digunakan untuk menghilangkan cemas dan stress, adapun tujuan dari latihan relaksasi yaitu untuk menghasilkan respon yang mampu menghambat stres dan jika tujuan ini sesuai dengan harapan maka hipotalamus menurunkan aktivitas sistem saraf simpatik dan parasimpatis sehingga hal tersebut dapat menghasilkan perasaan tenang dan santai.

Helen (20I5) mengemukakan bahwa Progressive Muscle Relaxation (PMR) merupakan salah satu teknik relaksasi dengan menggunakan gerakan mengencangkan otot kemudian melemaskan kembali otot-otot pada bagian tubuh tertentu dan dilakukan dalam satu waktu, sehingga hal tersebut akan memberikan perasaan relax. Gerakan mengencangkan otot kemudian melemaskan kembali otot tersebut dapat dilakukan secara bertahap. Ketika PMR dilakukan, pasien diarahkan melakukan kegiatan tersebut, pasien akan membedakan perasaan yang dialami saat dilemaskan dan kemudian pasien akan membandingkan kondisi-kondisi tersebut, sehingga pasien akan merasakan perbedaan yang sangat signifikan. Teknik relaksasi PMR juga dilaporkan efektif mengurangi ketegangan otot tubuh, adanya perubahan aktivitas dalam sistem saraf simpatik, penurunan denyut nadi, tekanan darah dan juga fungsi neuroendokrin pada pasien yang merasakan kecemasan

Berdasarkan gambaran diatas dapat dilihat bahwa kecemasan memiliki peran yang dapat mempengaruhi kondisi individu, terutama bagi individu yang memiliki riwayat penyakit, salah satu intervensi yang dapat digunakan untuk menurunkan kecemasan adalah Progressive Muscle Relaxation. Maka dari itu peneliti ingin mengetahui efektivitas PMR untuk menurunkan kecemasan 


\section{Metode}

Metode penelitian yang digunakan dalam penelitian ini yaitu menggunakan meta-analisis. Yue, Zhang, Zhang \& Jin (2017) mengemukakan bahwa meta-analisis dilakukan dengan mengeksplorasi perbedaan antara dua kelompok, yaitu kelompok kontrol dan kelompok eksperimen dengan melihat mean dan standar deviasi. Peneliti melakukan analisis data dengan menggunakan website Meta-mar (Free Online Meta-Analysis Service). Peneliti menggunakan pedoman dari PRISMA (Preferred Reporting Items for Systematic Reviews and Meta- Analysis) dan MARS (Meta-analysis Reporting Standards). Dalam penelitian yang dilakukan, peneliti melakukan sebuah penelusuran terhadap penelitian terdahulu dengan variabel progressive muscle relaxation dalam menurunkan kecemasan. Pencarian data berdasarkan dengan jurnal dan melakukan penelusuran menggunakan ScienceDirect, Google Scholar, dan Google.

Peneliti melakukan scanning atau menyeleksi artikel yang terkait dengan progressive muscle relaxation dan kecemasan dengan kriteria inklusi dan eksklusi dan telah ditetapkan yaitu dengan melihat effect size dan adanya kelompok eksperimen dan kelompok kontrol. Adapun kriteria inklusi yaitu menggunakan jurnal berbahasa inggris, menggunakan metode eksperimen dengan menyebutkan $N$, $M$ (mean) dan SD (standar deviasi). Adapun kriteria eksklusi yaitu jika ada publikasi ganda maka tidak digunakan Dari kriteria tersebut peneliti mendapatkan 14 jurnal internasional sejak tahun $2003-2020$.

\section{Tabel I}

Hasil pencarian literatrur

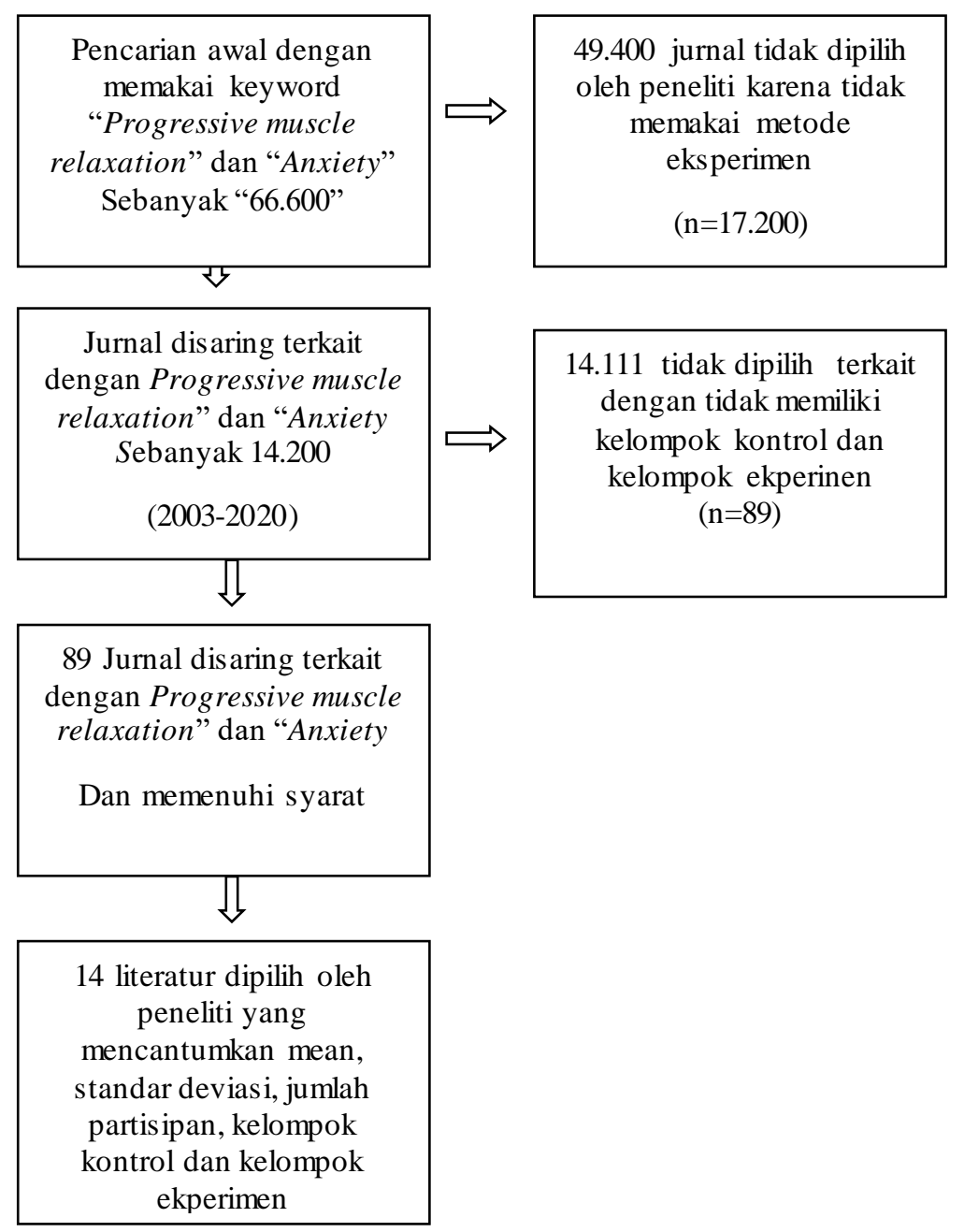


Peneliti melakukan pencarian awal dengan memakai keyword PMR dan kecemasan dan mendapatkan 66.600 jurnal, namun ada jurnal yang tidak terpilih dikarenakan tidak memiliki kriteria inklusi dan eksklusi, kriteria diatas dan setelah melakukan proses scanning, peneliti mendapatkan 14 literatur jurnal internasional.

\section{Pencarian literatur}

\section{Tabel 2}

Kumpulan Artikel Jurnal penelitian

\begin{tabular}{|c|c|c|c|c|c|c|}
\hline \multirow{2}{*}{ Peneliti } & \multirow{2}{*}{ Negara } & \multirow{2}{*}{$\begin{array}{c}\text { Partisipan } \\
\text { Usia }\end{array}$} & \multirow{2}{*}{$\begin{array}{c}\text { Skala } \\
\text { Kecemasan }\end{array}$} & \multicolumn{2}{|c|}{ Effect Size } & \multirow{2}{*}{$\begin{array}{c}\text { Interve } \\
\text { nsi }\end{array}$} \\
\hline & & & & K. K & K. E & \\
\hline $\begin{array}{c}\text { Kai liu, Ying chen, Duozhi } \\
\text { Ww, Ruzhenf lin, Zaisheng } \\
\text { wang, Liqing pan. } \\
(2020)\end{array}$ & China & 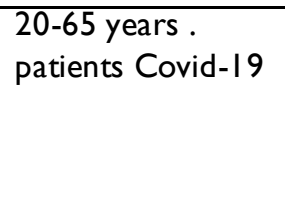 & $\begin{array}{l}\text { State Trait } \\
\text { Anxiety Scale } \\
\text { Inventory } \\
\text { (STAI) }\end{array}$ & $\begin{array}{l}\text { M; } 57,88 \\
\text { SD: II } .51 \\
\text { N: } 25\end{array}$ & $\begin{array}{l}\text { M: } \\
56.92 \\
\text { SD: } \\
7.92 \\
\text { N; } 26\end{array}$ & PMR \\
\hline $\begin{array}{l}\text { Sulastini, Medani, Fitria, } \\
\text { Nugraha } \\
(2019)\end{array}$ & Indonesia & $\begin{array}{l}\text { Congestive heart } \\
\text { failure patients. } \\
\text { Age } 26-65 \text { years }\end{array}$ & $\begin{array}{l}\text { Hamilton } \\
\text { Anxiety Rating } \\
\text { Scale (HARS) }\end{array}$ & $\begin{array}{l}\text { M: } 4.13 \\
\text { SD: } 4.65 \\
\quad N ; 23\end{array}$ & $\begin{array}{l}\text { M: } 1.74 \\
\text { SD: } \\
4.03 \\
\text { N; } 23\end{array}$ & PMR \\
\hline $\begin{array}{c}\text { Dominika wilczyiska, Anna } \\
\text { lysak-radomska, Magdalena } \\
\text { podczarska-glowacka, } \\
\text { Jolanta zajt, } \\
\text { Marcin dornowski, and } \\
\text { Pawel skonieczny } \\
(2019)\end{array}$ & Polandia & $20-25$ years & $\begin{array}{l}\text { State Trait } \\
\text { Anxiety Scale } \\
\text { Inventory } \\
\text { (STAI) }\end{array}$ & $\begin{array}{l}\text { M: } 25.0 \\
\text { SD: } 5.1 \\
\text { N: } 32\end{array}$ & $\begin{array}{l}\text { M: } 29.4 \\
\text { SD: } 7.0 \\
N ; 17\end{array}$ & PMR \\
\hline $\begin{array}{l}\text { Acık kalp ameliyatı olan } \\
\text { hastalarda, Endotrakeal } \\
\text { ekstubasyon sonrası, } \\
\text { Uygulanan Progresif Kas } \\
\text { Gevseme Egzersizlerinin }\end{array}$ & Turkish & $20-60$ & $\begin{array}{l}\text { State Trait } \\
\text { Anxiety Scale } \\
\text { Inventory } \\
\text { (STAI) }\end{array}$ & $\begin{array}{l}\text { M: } 25.63 \\
\text { SD: } 4.75 \\
\text { N; } 30\end{array}$ & $\begin{array}{l}\text { M: } \\
39.20 \\
\text { SD: } \\
10.09 \\
N ; 30\end{array}$ & PMR \\
\hline $\begin{array}{c}\text { Yasam Bulgularına ve Kaygı } \\
\text { Duzeyine Etkisi } \\
(2017)\end{array}$ & & & & & & \\
\hline $\begin{array}{c}\text { Martha L. Carver, \& } \\
\text { Maureen O'Malley PhD } \\
(2015)\end{array}$ & AS & Nursing students & $\begin{array}{l}\text { State Anxiety } \\
\text { Inventory (SAI) }\end{array}$ & $\begin{array}{l}\text { M: }-14.34 \\
\text { SD: } 3.55 \\
\quad N ; 7\end{array}$ & $\begin{array}{l}\text { M: - } \\
3.63 \\
\text { SD: } \\
4.24 \\
\quad \mathrm{~N} ; 8\end{array}$ & PMR \\
\hline $\begin{array}{c}\text { Yunping li, Ranran wang, } \\
\text { Jingqun tang, Chen chen, } \\
\text { Ling tan, Zhongshi wu, } \\
\text { Fenglei yu, \& Xiang wang. } \\
(2015)\end{array}$ & China & $\begin{array}{l}\text { Pulmonary } \\
\text { Arterial } \\
\text { Hypertension } \\
\text { Patients }\end{array}$ & $\begin{array}{l}\text { State Anxiety } \\
\text { Inventory (SAI) }\end{array}$ & $\begin{array}{l}\text { M: }-0.5 \\
\text { SD: } 3.4 \\
\text { N; } 55\end{array}$ & $\begin{array}{c}M:-2.4 \\
\text { SD: } 2.9 \\
N ; 59\end{array}$ & PMR \\
\hline $\begin{array}{c}\text { Kaina zhou, Xiaomei li, Jin li, } \\
\text { Miao liu, Shaonong dang, } \\
\text { Duolao wang, \& Xia xin } \\
(2014)\end{array}$ & China & $\begin{array}{l}\text { female gender, } \\
25-65 \text { age, } \\
\text { diagnosed with } \\
\text { breast cancer, and } \\
\text { arranged to have } \\
\text { radical } \\
\text { mastectomy. }\end{array}$ & $\begin{array}{l}\text { State Anxiety } \\
\text { Inventory (SAI) }\end{array}$ & $\begin{array}{l}\text { M: } 12.56 \\
\text { SD: I.03 } \\
\text { N; } 85\end{array}$ & $\begin{array}{l}\text { M: } \\
\text { I } 7.01 \\
\text { SD: } \\
2.46 \\
N ; 85\end{array}$ & PMR \\
\hline $\begin{array}{c}\text { Herizchi, Asvadi, Piri, } \\
\text { Golchin, Shabanlui, Sanaat } \\
(2012)\end{array}$ & Iran & $\begin{array}{l}\text { Patient } \\
\text { emotherapy in } \\
\text { the tabriz } \\
\text { hematology, I5- } \\
65 \text { age }\end{array}$ & $\begin{array}{l}\text { Hospital } \\
\text { Anxiety \& } \\
\text { Depression } \\
\text { Scale (HADS) }\end{array}$ & $\begin{array}{c}M: 35.63 \\
\text { SD: } 5.56 \\
N ; 30\end{array}$ & $\begin{array}{l}\text { M: } \\
40.50 \\
\text { SD: } \\
7.05 \\
\text { N; } 30\end{array}$ & PMR \\
\hline $\begin{array}{l}\text { Nahid dehghan-nayeri, \& } \\
\text { Mohsen adib-hajbaghery }\end{array}$ & Iran & $\begin{array}{l}\text { Famile, students } \\
\text { in four }\end{array}$ & $\begin{array}{l}\text { State Anxiety } \\
\text { Inventory (SAI) }\end{array}$ & $\begin{array}{l}\text { M: }-5.13 \\
\text { SD: } 9.84\end{array}$ & $\begin{array}{l}\text { M: } 2.96 \\
\text { SD: }\end{array}$ & PMR \\
\hline
\end{tabular}


(20II)

Funda Büyükyılma, PhD, RN, Turkish dan Turknaz Astı, PhD, RN

(2010)

$$
\begin{aligned}
& \text { VP singh, V rao, Prem v India } \\
& \text { sahoo RC, \& } \\
& \text { Keshav pai k } \\
& \text { (2009) }
\end{aligned}
$$

Wen-chun chen, Hsin chu, Taiwan Ru-band lu, Yuan-hwa chou, Chung-hua chen, Yue-cune chang, Anthony paul o'brien

$$
\text { \& Kuei-ru chou }
$$
(2009)

Hee j. Yoo, se h. ahn, Sung Seoul, b. kim, Woo k, kim \& Oh s. south han (2005)

Yuk lung cheung, Alexander China molassiotis, \& Anne m. chang (2003) dormitories of TUMS

Arthroplasty

korea

cancer patients after stoma surgery.

Chronic obstructive pulmonary patients with acute schizophrenia
$\mathrm{N} ; 100$

13.36

$\mathrm{N} ; 100$

State Anxiety

Inventory (SAI) disease (COPD)

State Anxiety Inventory (SAI)

Beck Anxiety Inventory (BAl)

patients with
breast cancer
cancer patients
after stoma
surgery.

Multiple affect adjective checklist

(MAACL)

cancer patients after stoma surgery.
M: 25.78

M:

SD: $6.63 \quad 34.70$

$\mathrm{N} ; 30$ SD:

6.12

N; 30

M: 4.2

M: 2.44

SD: 3.3 SD: 1.8

$\mathrm{N} ; 32 \mathrm{~N} ; 32$

M: 16.4

M: 15.0

SD: 4.4

SD: 3.9

$\mathrm{N} ; 8 \quad \mathrm{~N} ; 6$

M: 7.01

M: 9.75

PMR

$\mathrm{N}: 30 \quad 3.48$

$\mathrm{N} ; 30$

PMR

PMR

PMR

M: $31.27 \quad M:$

SD: $3.11 \quad 42.83$

N: 29 SD:

4.24

N: 30

Tabel diatas merupakan I 4 jurnal internasional sejak tahun 2003 - 2020 yang digunakan oleh peneliti dan juga memiliki kriteria yang telah ditetapkan yaitu adanya kelompok kontrol dan

\begin{tabular}{|c|c|c|c|c|c|c|c|}
\hline Peneliti & Negara & $\begin{array}{c}\text { Partisipan } \\
\text { Usia }\end{array}$ & $\begin{array}{c}\text { Skala } \\
\text { kecemasan }\end{array}$ & $\mathbf{g}$ & SEg & $\begin{array}{c}\mathbf{g} \\
\text { lowwer }\end{array}$ & $\begin{array}{c}\mathbf{g} \\
\text { upper }\end{array}$ \\
\hline $\begin{array}{c}\text { Kai liu, Ying } \\
\text { chen, Duozhi }\end{array}$ & China & $\begin{array}{l}20-65 \text { years. } \\
\text { patients }\end{array}$ & $\begin{array}{l}\text { State Trait } \\
\text { Anxiety }\end{array}$ & $\begin{array}{c}- \\
0.096027\end{array}$ & 0.275964 & $\begin{array}{c}- \\
0.636917\end{array}$ & 0.444863 \\
\hline $\begin{array}{l}\text { Ww, Ruzhenf lin, } \\
\text { Zaisheng wang, } \\
\text { Liqing pan. } \\
(2020)\end{array}$ & & Covid-19 & $\begin{array}{l}\text { Scale } \\
\text { Inventory } \\
\text { (STAI) }\end{array}$ & & & & \\
\hline $\begin{array}{l}\text { Sulastini, Medani, } \\
\text { Fitria, Nugraha } \\
(2019)\end{array}$ & Indonesia & $\begin{array}{l}\text { Congestive } \\
\text { heart failure } \\
\text { patients. Age } \\
26-65 \text { years }\end{array}$ & $\begin{array}{l}\text { Hamilton } \\
\text { Anxiety } \\
\text { Rating Scale } \\
\text { (HARS) }\end{array}$ & $\begin{array}{c}- \\
0.539875\end{array}$ & 0.295244 & I.II8553 & 0.038802 \\
\hline $\begin{array}{c}\text { Dominika } \\
\text { wilczyiska, Anna } \\
\text { lysak-radomska, } \\
\text { Magdalena } \\
\text { podczarska- } \\
\text { glowacka, Jolanta } \\
\text { zajt, }\end{array}$ & Polandia & $20-25$ years & $\begin{array}{l}\text { State Trait } \\
\text { Anxiety } \\
\text { Scale } \\
\text { Inventory } \\
\text { (STAI) }\end{array}$ & $0.74428 I$ & 0.304728 & 0.147014 & I.34I 548 \\
\hline
\end{tabular}
kelompok eksperimen, mencantumkan $\mathrm{M}, \mathrm{SD}$, dan $\mathrm{N}$.

\section{Hasil Meta Analisis}

Tabel 3

Hasil analisis jurnal penelitian menggunakan situs web Meta-mar 


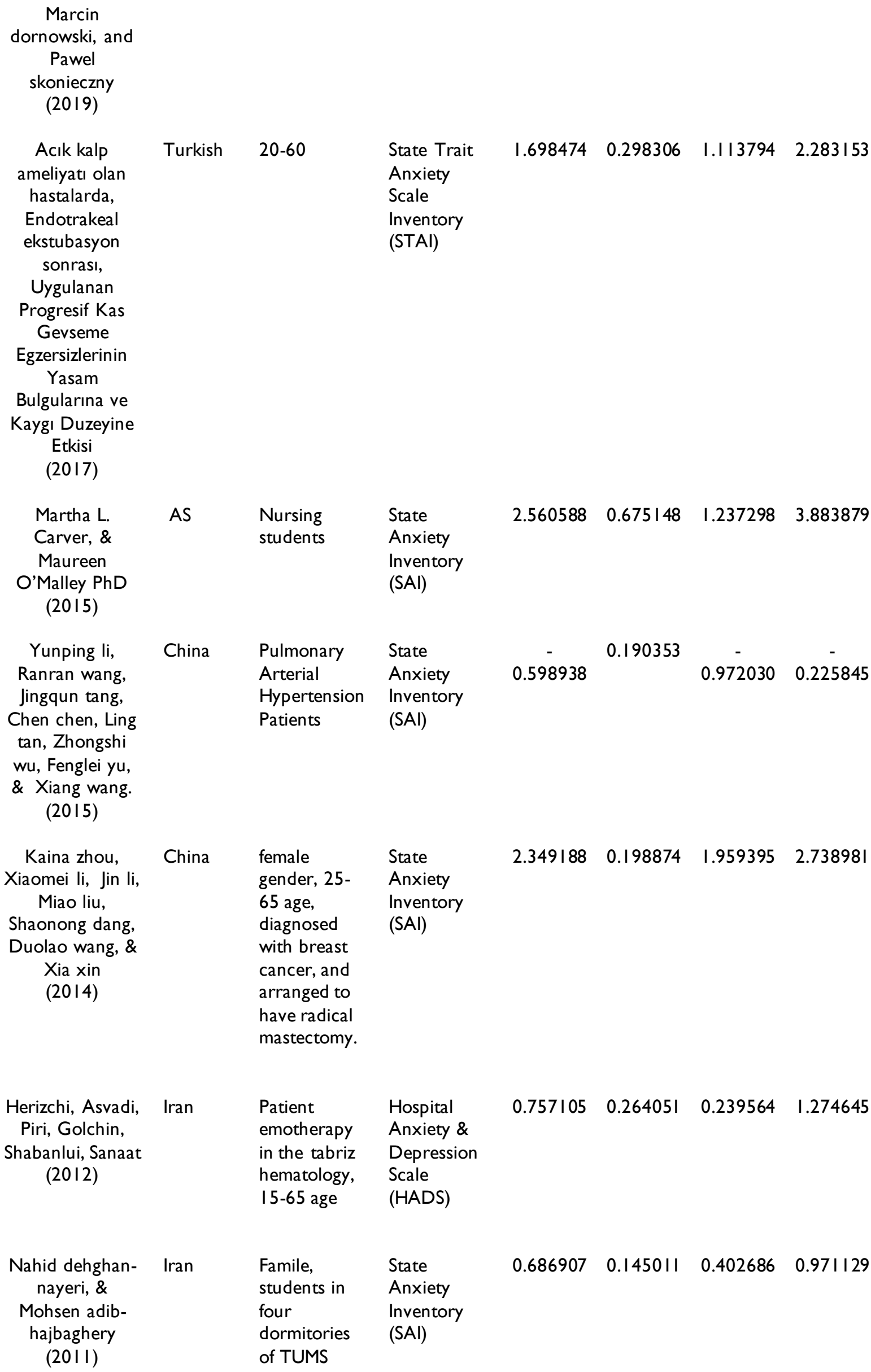

Famile, students in

four

State

0.598938

0.190353

$0.972030 \quad 0.225845$

dormitories (SAI)

of TUMS 


\begin{tabular}{|c|c|c|c|c|c|c|c|}
\hline $\begin{array}{c}\text { Funda } \\
\text { B€uy€ukyılmaz, } \\
\text { PhD, RN, dan } \\
\text { T€urkinaz As,tı, } \\
\text { PhD, RN } \\
(20 \mid 0)\end{array}$ & Turkish & Arthroplasty & $\begin{array}{l}\text { State } \\
\text { Anxiety } \\
\text { Inventory } \\
\text { (SAI) }\end{array}$ & I.37994| & 0.284280 & 0.822752 & 1.937129 \\
\hline $\begin{array}{l}\text { VP singh, V rao, } \\
\text { Prem v sahoo } \\
\text { RC, \& } \\
\text { Keshav pai k } \\
\text { (2009) }\end{array}$ & India & $\begin{array}{l}\text { Chronic } \\
\text { obstructive } \\
\text { pulmonary } \\
\text { disease } \\
\text { (COPD) }\end{array}$ & $\begin{array}{l}\text { State } \\
\text { Anxiety } \\
\text { Inventory } \\
\text { (SAI) }\end{array}$ & 0.654108 & 0.253641 & $\frac{-}{1.151244}$ & 0.156972 \\
\hline $\begin{array}{l}\text { Wen-chun chen, } \\
\text { Hsin chu, Ru- } \\
\text { band lu, Yuan- } \\
\text { hwa chou, } \\
\text { Chung-hua chen, } \\
\text { Yue-cune chang, } \\
\text { Anthony paul } \\
\text { o'brien \& Kuei- } \\
\text { ru chou } \\
\text { (2009) }\end{array}$ & Taiwan & $\begin{array}{l}\text { patients with } \\
\text { acute } \\
\text { schizophrenia }\end{array}$ & $\begin{array}{l}\text { Beck } \\
\text { Anxiety } \\
\text { Inventory } \\
\text { (BAl) }\end{array}$ & 0.312138 & 0.509019 & 1.309816 & 0.685540 \\
\hline $\begin{array}{l}\text { Hee j. Yoo, se h. } \\
\text { ahn, Sung b. kim, } \\
\text { Woo k, kim \& } \\
\text { Oh s. han } \\
(2005)\end{array}$ & $\begin{array}{l}\text { Seoul, } \\
\text { south } \\
\text { korea }\end{array}$ & $\begin{array}{l}\text { patients with } \\
\text { breast cancer }\end{array}$ & $\begin{array}{l}\text { Multiple } \\
\text { affect } \\
\text { adjective } \\
\text { checklist } \\
\text { (MAACL) }\end{array}$ & $0.74 I I 93$ & 0.263675 & 0.224391 & I.257996 \\
\hline $\begin{array}{l}\text { Yuk lung cheung, } \\
\text { Alexander } \\
\text { molassiotis, \& } \\
\text { Anne m. chang } \\
\text { (2003) }\end{array}$ & China & $\begin{array}{l}\text { cancer } \\
\text { patients after } \\
\text { stoma } \\
\text { surgery. }\end{array}$ & $\begin{array}{l}\text { cancer } \\
\text { patients } \\
\text { after stoma } \\
\text { surgery. }\end{array}$ & 3.059909 & 0.381292 & 2.312577 & 3.807240 \\
\hline
\end{tabular}

Berdasarkan I 4 penelitian diatas, perhitungan statistik yaitu menggunakan effect size dari kelompok eksperimen dan kelompok kontrol untuk menunjukkan efektivitas progressive muscle relaxation menurunkan kecemasan. Berdasarkan nilai effect size dengan menggunakan random effect dikarenakan adanya perbedaan alat ukur penelitian yang digunakan dan nilai inconsistency $\mathrm{I}^{2}$ yaitu sebesar $94,5 \%$.

\section{Tabel 4}

Hasil analisis effect size menggunakan Fixed Effect Model dan Random Effect Model

\begin{tabular}{ccccccc}
\hline & $\begin{array}{c}\text { Hedges'g } \\
(\mathrm{SMD})\end{array}$ & $\mathrm{SEg}$ & $95 \% \mathrm{Cl}$ & z score & P value & Heterogeneity \\
\hline $\begin{array}{c}\text { Fixed } \\
\text { Effect } \\
\begin{array}{c}\text { Model } \\
\text { Random } \\
\text { Effect } \\
\text { Model }\end{array}\end{array}$ & 0.69 & 0.068 & {$[0.555,0.82 \mathrm{I}]$} & 10.128 & 0.0 & $\mathrm{I}^{2}=94.5 \%, \mathrm{Chi}^{2}=236.64$, \\
$\mathrm{df}=13$
\end{tabular}

Dilihat dari kolom diatas, nilai Hadges'g (SMD) yang digunakan sebesar 0,8 $(95 \% \mathrm{Cl}=0,224$ sampai $\mathrm{I} .40 \mathrm{I}, \mathrm{p}=0.00068446)$. Penelitian ini menggunakan analisis statistik cohen $d$ effect size dalam menjelaskan aturan mengenai small effect size $(d \leq 0,2)$, medium effect size $(0,2 \leq d \leq 0,8)$, dan large effect size $(d \geq 0,8)$. Berdasarkan kategori tersebut penelitian ini memperlihatkan kategori large 
effect size, hal ini menunjukkan bahwa progressive muscle relaxation memberikan efek yang besar dalam menurunkan kecemasan.

\section{Gambar I}

Forestplot - fixed effect models dan random effect models

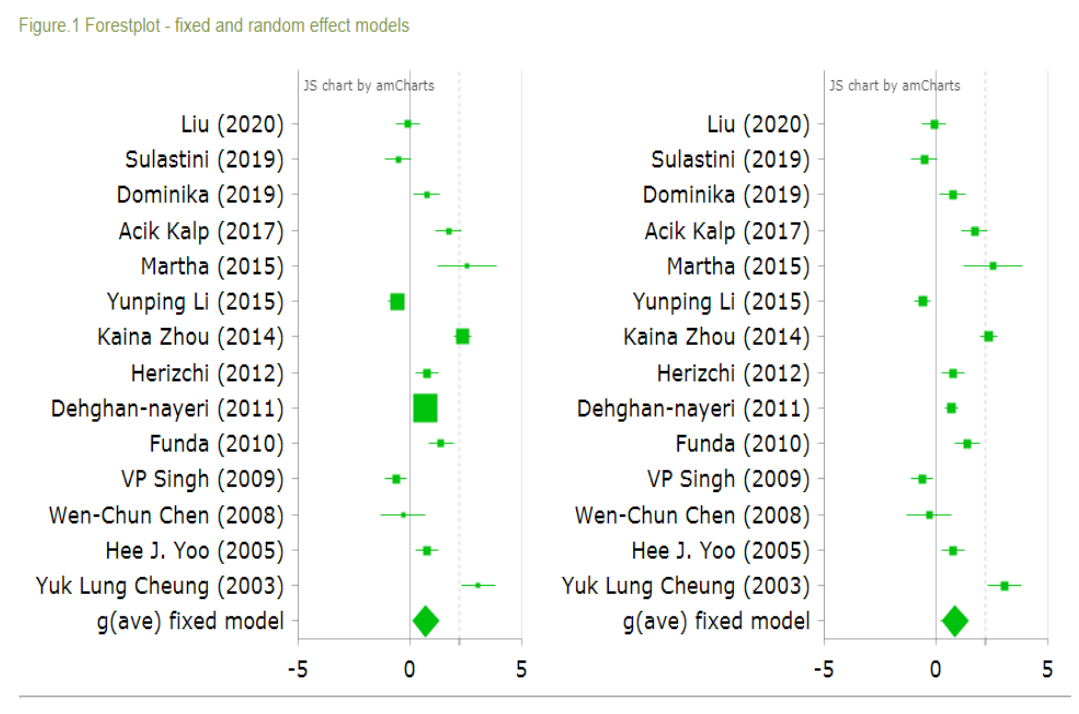

\section{Pembahasan}

Pada hasil studi meta-analisis dengan menggunakan literatur 14 jurnal internasional semakin memperkuat bahwa progressive muscle relaxation dapat secara efektif menurunkan kecemasan dilihat dari hasil meta-analisis, nilai Hedges'g diperoleh sebesar 0,8I yang berarti diketahui bahwa progressive muscle relaxation efektif untuk menurunkan kecemasan bagi, individu di perguruan tinggi yang memiliki praktik kuliah di rumah sakit, maupun individu yang memiliki riwayat penyakit kronis dan membutuhkan pengobatan seumur hidup seperti pasien penderita kanker (Ricky, dkk 2018; Zhou, dkk 20 I4); jantung (Sulastini, dkk 20 I9); hipertensi (li,dkk 20 I 5); bahkan untuk pasien covid19 (Lin, dkk 2020).

Deghan-Nyeri (20II) mengemukakan bahwa kecemasan adalah salah satu respon yang paling umum terjadi terhadap siswa sekolah keperawatan, dan kedokteran. Adapun faktor-faktor yang mempengaruhi kecemasan diantaranya adalah keuangan, praktek sambil belajar, bergaul dengan teman, waktu tidur yang terganggu, beban belajar yang berlebihan, tidak adanya layanan konseling dan harapan keluarga. Diagnosis yang diberikan kepada individu yang memiliki penyakit atau membutuhkan perawatan seumur hidup dapat mempengaruhi setiap aspek kehidupan pasien, seperti aspek fisik psikologis, vokasional dan spiritual. Individu yang tidak bisa menghadapi kenyataan cenderung menghindar, dan penghindaran tersebut menjadi faktor resiko munculnya gangguan psikologis seperti cemas, stress dan depresi. Ricky, dkk (2018) mengemukakan bahwa bagi pasien kanker ovarium pemilihan pengobatan sangat mempengaruhi proses kemoterapi yang akan dijalankan. PMR mampu menurunkan intensitas mual dan muntah saat menjalani kemoterapi. Teknik relaksasi juga telah terbukti lebih efektif untuk menghilangkan kecemasan pada pasien kanker, yaitu PMR(zhou dkk, 20I4).

PMR merupakan salah satu intervensi yang memiliki banyak manfaat pada kehidupan dan kesehatan manusia (Joy, Jose, \& Nayak 20I4). Smeltzer (20l3) mengemukakan bahwa teknik relaksasi merupakan salah satu metode utama yang mampu menurunkan stress. Salah satu terapi yang dapat membuat individu menjadi relax yaitu progressive muscle relaxation. progressive muscle relaxation 
merupakan terapi yang mengencangkan otot-otot tertentu lalu kemudian melemaskan otot-otot tersebut, sehingga memberikan perasaan relax pada individu, dan dapat menurunkan tingkat stress dan cemas yang dirasakan oleh individu (Avianti dkk, 20l6).

Kecemasan yang dialami oleh pasien kanker dapat timbul akibat perasaan ketidakpastian tentang penyakit, pengobatan, prognosis. Kecemasan yang tidak diatasi dengan baik akan menimbulkan rangsangan pada kortek serebri yang dapat menstimulasi pusat muntah, sehingga memungkinkan terjadinya peningkatan keluhan mual dan muntah akibat kemoterapi. Kecemasan juga dapat memperberat keluhan mual dan muntah, mual dan muntah juga dapat menyebabkan kecemasan, sehingga hal ini disebut sebagai lingkaran setan dan harus diputuskan. Untuk mengatasi efek psikologi pada pasien kanker yaitu dengan cara relaksasi. Terapi relaksasi dilakukan agar pasien secara sadar mengendalikan aktivitas faal dan psikis, memperbaiki kondisi disfungsi faal dan psikis, sehingga hal tersebut mampu menstabilkan emosi dan mengatasi gejala penyakit yang diderita terutama kecemasan akibat regimen kemoterapi (Syarfi \& Putra, 20 I4).

Kecemasan yang terjadi pada pasien covid- 9 dikarenakan perasaan ketidakpastian yang berasal dari virus itu sendiri, dimana virus covid-19 ini merupakan virus jenis baru yang belum diketahui penyebab dan pengobatannya, serta proses penularannya yang sangat cepat dan juga tingkat kejadian dan kematian yang cukup tinggi. Pasien yang didiagnosis dengan covid - I 9 harus di isolasi ruangan terpisah sehingga menyebabkan kecemasan dan gangguan tidur selama perawatan isolasi Lin dkk (2020).

Kecemasan dapat mempengaruhi kualitas hidup seseorang misalnya waktu tidur yang berkurang. Lin, dkk (2020) dalam penelitiannya menjelaskan bahwa PMR mampu mengurangi kecemasan dan meningkatkan kualitas tidur pada pasien covid-19, pada wanita muda yang mengalami prenatal anxiety, dan pada wanita dengan kanker payudara. Wilczyńska, Lysak-radomska, Podczarskagłowacka, Zajt, Dornowski, \& Skonieczny (2019) dalam penelitiannya yaitu melihat tingkat kecemasan peserta berdasarkan gender yang dilakukan di Universitas Gdansk, memperlihatkan bahwa PMR tidak hanya berfokus pada satu gander tapi PMR dapat diterapkan baik pada pria maupun wanita. Hal ini diperkuat dengan penelitian yang dilakukan oleh lin dkk (2020) dalam penelitiannya juga memperlihatkan bahwa PMR dapat diberikan oleh pria maupun wanita. Oleh karena itu dapat disimpulkan bahwa PMR dapat diterapkan pada pasien kanker dan juga covid-19 baik pria maupun wanita.

PMR merupakan suatu prosedur untuk mendapatkan relaksasi otot melalui dua Langkah. Langkah pertama apakah dengan memberikan tegangan pada suatu kelompok otot, dan kedua dengan menghentikan tegangan kemudian memusatkan perhatian terhadap bagaimana otot tersebut menjadi rileks, dan merasakan sensasi relax secara fisik ketika tegangannya menghilang. Latihan PMR melibatkan pernafasan dengan mengikuti irama dalam pernafasan. Pada dasarnya PMR menggunakan melibatkan konsentrasi dan relaksasi antar berbagai kelompok otot mulai dari kaki ke arah atas atau dari kepala ke bawah. Hal tersebut dapat memberikan sensasi relax memberikan ketenangan dan menghilangkan kecemasan (Utami, 20I8).

Synder \& Lindquist (Utami, 2018) mengemukakan bahwa teknik PMR dikembangkan oleh Berstein dan Brorkovec yang mengkombinasikan 108 otot-otot dan kelompok otot, namun Jacabson menguranginya menjadi 16 kelompok otot sehingga lebih mudah diterapkan secara mandiri. Astuti \& suandika (2015) menyarankan untuk hasil yang maksimal dianjurkan untuk berlatih PMR dua kali sehari dengan jam yang sama selama 20-30 menit. Latihan bisa dilakukan pagi dan sore hari dan sebaiknya dilakukan 2 jam setelah makan. PMR sebaiknya dibuatkan jadwal latihan dengan durasi waktu seminggu dan menganjurkan menggunakan minimal 10 kelompok otot dalam 10 sesi latihan, sehingga memperlihatkan hasil yang maksimal. 


\section{Kesimpulan}

Berdasarkan hasil penelitian dapat disimpulkan bahwa hipotesis penelitian diterima, artinya PMR memiliki efek yang besar dalam menurunkan kecemasan. Hal tersebut dilihat pada hasil effect size dengan kategori large. Heterogenitas pada meta-analysis ini juga tinggi, hal tersebut dapat terjadi karena variasi data. Adapun keterbatasan pada studi ini yaitu peneliti belum dapat memfokuskan skala pengukuran kecemasan pada satu jenis, bagi peneliti selanjutnya dapat memfokuskan pada satu pengukuran kecemasan.

PMR mampu menurunkan tingkat kecemasan pada pasien kanker yang sedang mengikuti kemoterapi, bukan hanya mampu menurunkan kecemasan tapi PMR juga mampu mengurangi mual dan muntah pada pasien setelah mengikuti kemoterapi. PMP juga mampu menurunkan kecemasan pada pasien covid-19 dan juuga meningkatkan kualitas tidur, sehingga hal tersebut dapat memberikan dampak positif dalam proses penyembuhan pasien covid-19, pasien diabetes, pasien dengan kanker, bahkan pada mahasiswi di perguruan tinggi yang memiliki praktik kerja di rumah sakit.

Teknik relaksasi yang dipilih dengan benar seperti PMR secara signifikan dapat mempengaruhi tingkat kecemasan, mengurangi gejala depresi dan relaksasi juga mampu memberikan perasaan rileks sehingga menghilangkan nyeri yang terjadi akibat dari peningkatan otot karena ketegangan. Namun tidak ada satupun teknik relaksasi yang cocok untuk semua orang. Individu harus mempertimbangkan kebutuhan dan preferensi yang dialami sebelum memilih teknik relaksasi.

\section{REFERENSI}

Astuti, D \& Suandika, M. ( 2015 ). Efektifitas pemberian terapi relaksasi otot progresif dan nafas dalam terhadap penururnan I somnia pada lansia di unit rehabilitasi sosial dewanata Cilacap. Semarang : Jurusan Keperawatan FK Undip.

Avianti, N., Desmaniarti,Z., Rumahorbo, H. (2016). Progressive muscle relaxation effectiveness of the blood sugar patients with type 2 diabetes. Open Journal of Nursing. 6. 248-254. Doi: 10.4236/ojn.2016.63025.

Annisa, D, F., Ifdil. (20I6). Konsep kecemasan (anxiety) pada lanjut usia. Jurnal Konselor. 5(2). 93 99. Doi: 10.24036/02016526480-0-00

B€uy€ukyılmaz, $\mathrm{F} \& \mathrm{As}, \mathrm{tl}, \mathrm{T} .(20 \mid 0)$. The effect of relaxation techniques and back massage on pain and anxiety in turkish total hip or knee arthroplasty patients. Pain Management Nursing. I4(3). I43-I54. Doi: 10.1016/j.pmn.2010.1 I.001.

Carver, M. L. \& O'Malley, M. (20I5). Progressive muscle relaxation to decrease anxiety in clinical simulations. Journal Teaching and Learning in Nursing. 10 (2). 57-62. Doi: 10.1016/j.teln.2015.01.002.

Cheung, L. Y., Molassiotis, A., \& Chang, (2003). The effect of progressive muscle relaxation training on anxiety and quality of life after stoma surgery in colorectal cancer patients. Jurnal Of Psycho-Oncology. I2(I). 254-266. Doi: I0.1002/638.

Chen, w., Chu, H., Chou, Y., Chen, C., Chang, Y., O'brien, A. P., \& Chou, K. (2008). Efficacy of progressive muscle relaxation training in reducing anxiety in patients with acute schizophrenia. Journal of Clinical Nursing. I8(15). 2187-2196.

Doi: 10.1 I I I/j. I365-2702.2008.02773.x

Dehghan-nayeri, N., \& Adib-Hajbaghery, M., (20II). Effects of progressive relaxation on anxiety and quality of life in female students: A non-randomized controlled trial. Journal of sciene direct. 19(4). 194-200. Doi: 10.1016/j.ctim.2011.06.002.

Hastalarda, A. K. A., \& Etkisi, E. E. S. U. P. (2017). The effect of progressive muscle relaxation exercises after endotracheal extubation on vital signs and anxiety level in open heart surgery patients. Turk Journal Intense Care. I5(I). 98-106. Doi: 10.4274/tybd.04696. 
Helen, C., (20I5). Progressive muscle relaxation. Cam-cancer consortium: Retrieved from http://www.cam-cancer.org/The-Summaries/Mind-bodyinterventions/Progressive-MuscleRelaxation [Accessed Mei 19, 2020]

Herizchi, S., Asvadi, I., Piri, I., Golchin, M., Shabantui, R., \& Sanaat, Z. (2012). Efficacy of progressive muscle relaxation training on anxiety, depression and quality of life in cancer patients undergoing chemotherapy at tabriz hematology and oncology research center, Iran in 2010 . Middel East Journal Of Cancer. 2(I). 9-I3.

Joy, E. F., Jose, T. T., \& Nayak, K. A. (20/4). Effectivieness of jacobson's progressive muscle relaxation (jpmr) technique on social anxiety amoung high school adolescents in a selected school of Udupi District, Karnataka State Nitte University. Journal of Healthy Science. 4(I). 86-90. DOI: 10.1055/s-0040-I 703737

Kehoe (2017). Generalized Anxiety Disorder. ACSP 2017 Book 2. Neurologic/Psychiatry Care. Kartono, K. ( 1989). Hygiene mental dan kesehatan mental dalam Islam. Bandung: Mandar Maju.

Liu, K., Chen, Y., Wu, D., Lin, R., Wang, Z., Pan, L. (2020). Effects of progressive muscle relaxation on anxiety and sleep quality in patients with covid- 19. Jurnal Pre-Proof. I (20).I-9. Doi: 10.1016/J.Ctcp.2020.101132.

Li, Y., Wang, R., Tang, J., Chen, C., Tan, L., Wu, Z., Yu, F., \& Wang, X. (20I5). Progressive muscle relaxation improves anxiety and depression of pulmonary arterial hypertension patients. Evidence-Based Complementary and Alternative Medicine: eCAM, 20 I5(792895). I-8. Doi: $10.1155 / 2015 / 792895$.

Lee, E-J., Bhattacharya, J., Shon, C. \& Verres, P. (20I2). Monochord sounds and progressive muscle relaxation reduce anxiety and improve relaxation during chemotherapy: A pilot EEG study. Complementary Therapies In Medicine. 20(6). 409-4 I6. Doi: I0.1 0 I6/j.ctim.20 I2.07.002.

Ricky, Z., Rachmawaty, R., \& Syam, Y. (20I8). Efektifitas progressive muscle relaxation terhadap kecemasan pada pasien kanker payudara yang menjalani kemoterapi. Jurnal Terpadu IImu kesehatan. 7(2). I0I-2 I I. Doi:I0.3734I/interest. v7i2.38

Rochman, L. K. (2010) Kesehatan Mental. Purwokerto: Fajar Media Pers

Sarwono, S. W (2012). Pengantar Psikologi Umum. Jakarta: Rajawali Pers.

Syarif, H. \& Putra, A. (20I4). Pengaruh progressive muscle relaxation terhadap penurunan kecemasan pada pasien kanker yang manjalani kemoterapi a rendomized clincal trial. Idea Nursing Journal. 5(3). I -8. Retrieved from http://www.jurnal.unsyiah.ac.id/INJ/article/view/6560

Singh. V., Rao, V., Prem, V., Rc, S \&, Pai K, K. (2009). Comparison of the effectiveness of music and progressive muscle relaxation for anxiety in copd-a randomized controlled pilot study. Jorunal Chronic Resporatory Diases. 6(4). 209-2 I 6. Doi:I 0.I I 77/I 479972309346754.

Sulastini., Meidiani, H, Z., Fitria, N., Dan Nugraha, B, A. (2019). Effect of progressive muscle relaxation on anxiety in congestive heart failure patients. Jurnal Keperawatan Seodirman. I4(2). 80-86. Doi: 10.20884/I. Jks.2019.14.2.8I6.

Smeltzer, S.C.O. et al., (20I3). Brunner \& suddarth's textbook of medical- surgical nursing 10 th ed., USA: Wolters Kluwer Health/Lippincott Williams \& Wilkins, 530 Walnut Street, Philadelphia.

Utami, S. (20I6). Efektifitas latihan progressive muscle relaxation (PMR) terhadap mual muntah kemoterapi pasien kanker ovarium. Junal Keperawatan. 4 (2). 83-90.

Wilczyńska, D., Łysak-Radomska, A., Podczarska-Głowacka, M., Zajt, J., Dornowski, M., \& Skonieczny, P. (2019). Evaluation of the effectiveness of relaxation in lowering the level of anxiety in young adults - a pilot study. International Journal of Occupational Medicine And Environmental Health.32(6). 817-824. Doi: 10.13075/ijomeh.1896.0I457.

Yue, M., Zhang, M., Zhang, C., \& Jin, C. (2017). The effectiveness of concept mapping on development of critical thinking in nursing education: a systematic review and meta-analysis. Journal Nurse Education. 7(17). I -38. Doi: 10.1016/j.nedt.2017.02.018.

Yoo, H. J., Ahn, S. H., Kim, S. B., Kim, W. K., \& Han, S. O. (2005). Efficacy of progressive muscle relaxation training and guided imagery in reducing chemotherapy side effects in patients with breast cancer and in improving their quality of life. Jurnal of Support Care Cancer. I 3(10) 826-833. Doi: 10.1007/s00520-005-0806-7. 
Zhou, K., Li, X., li, J., Liu, M., Dang, S., Wang, D. \& Xin, X. (20|4). A clinical randomized controlled trial of music therapy and progressive muscle relaxation training in female breast cancer patients after radical mastectomy: Results on depression, anxiety and length of hospital stay. European Journal of Oncology Nursing. 19(1). I-6.

Doi: I0.1016/j.ejon.2014.07.010. 